\title{
Productivity of castor bean plants intercropped at different plant densities with Urochloa ruziziensis
}

\author{
Carlos F. dos S. Cordeiro ${ }^{1}$, Fábio R. Echer ${ }^{2}$, Lucas H. T. Pires ${ }^{1} \&$ José E. Creste $^{1}$
}

${ }^{1}$ Universidade do Oeste Paulista/Faculdade de Ciências Agrárias/Curso de Agronomia. Presidente Prudente, SP. E-mail: cordeirocfs@gmail.com (Corresponding author) - ORCID: 0000-0003-2111-8123; lucasteixeirapires@gmail.com - ORCID: 0000-0002-0241-8246; jcreste@unoeste.br - ORCID: 0000-0002-1971-4949

${ }^{2}$ Universidade do Oeste Paulista/Faculdade de Ciências Agrárias/Programa de Pós-Graduação em Agronomia. Presidente Prudente, SP. E-mail: fabioecher@unoeste.br - ORCID: 0000-0003-0140-7999

\begin{abstract}
Castor bean is an important raw material to produce biofuel in Brazil and can be grown in several regions of the country due to its good adaptation and tolerance to high temperatures and water deficit. The objective of this study was to evaluate the productivity of castor bean plants intercropped at different plant densities with Urochloa ruziziensis. The experiment was conducted in a randomized block design with four replications, using a $4 \times 2$ factorial arrangement, consisting of four plant densities $(13,574,24,512,36,816$, and 40,723 plants ha-1) of castor bean and two crop systems (single crop, and intercrop with Urochloa ruziziensis). The data were subjected to analyses of variance and regression, and means were compared by the Tukey's test $(\mathrm{p}<0.05)$. The intercrop system reduced the number of pods per plant by $15 \%$, but it did not significantly affect the castor bean grain yield. Increasing plant density reduced linearly the proportion of plants harvested, reaching $22.1 \%$, from the lowest to the highest plant density used; the highest grain yield was achieved using 36,816 plants ha ${ }^{-1}$ for both intercrop and single crop systems. Intercropping castor bean with U. ruziziensis does not reduce the castor bean grain yield and is an alternative to produce biomass for following crops, especially in production environments with low fertility soils, high temperatures, and infrequent rainfall.
\end{abstract}

Key words: Ricinus communis L., crop system, second crop, soil conservation, intercrop

\section{Produtividade da mamona em diferentes populações de plantas consorciadas com Urochloa ruziziensis}

\begin{abstract}
RESUMO: A mamoneira é uma importante matéria-prima para a produção de biocombustível, podendo ser cultivada em diversas regiões do país devido sua boa adaptação e tolerância às altas temperaturas e déficit hídrico. O objetivo deste trabalho foi avaliar a produtividade da mamona em diferentes populações de plantas consorciadas com Urochloa ruziziensis. O delineamento experimental foi em blocos ao caso em esquema fatorial de 4 × 2 com 4 repetições, o primeiro fator foi composto pelas densidades de plantas de mamona $\left(13574,24512,36816,40723\right.$ plantas ha $\left.{ }^{-1}\right)$, e o segundo fator constou da presença ou da ausência de Urochloa ruziziensis. A análise estatística constou da análise de variância e de regressão, e as médias foram comparadas pelo teste de Tukey $(\mathrm{p}<0,05)$. O consórcio reduziu em $15 \%$ o número de bagas por planta, mas não afetou significativamente a produtividade. $\mathrm{O}$ aumento da população de plantas reduziu linearmente a proporção de plantas colhidas $(22,1 \%$ da menor para a maior população) e a produtividade máxima foi atingida com 36816 plantas $\mathrm{ha}^{-1}$, tanto para a mamona consorciada quanto para a solteira. Concluiu-se que o consórcio da mamona com U. ruziziensis não reduz a produtividade da mamoneira e é uma alternativa para produção de palhada para as culturas sucessoras, especialmente em ambientes de produção com solos de baixa fertilidade, altas temperaturas e inconstância pluviométrica.
\end{abstract}

Palavras-chave: Ricinus communis L., sistema de cultivo, segunda safra, conservação do solo, consórcio 


\section{INTRODUCTION}

Brazil has one of the smallest grain yields of castor bean (Ricinus communis L.) among the producing countries, with an average of approximately $300 \mathrm{~kg} \mathrm{ha}^{-1}$ (Sá et al., 2015), because of the low use of technology in the production systems. Crops that use high technology reach grain yields of up to $4,000 \mathrm{~kg} \mathrm{ha}^{-1}$ (Savy Filho \& Banzatto, 1990) due to correct choice of cultivar, sowing density, and crop system.

The use of conservationist techniques for soil management, such as no-tillage system, is essential to reduce adverse effects of the climate on crops. Thus, the maintenance of soil coverage is one of the most important factors for soil conservation and one of the most complex factors to be managed in regions with low water availability, which hinders the establishment of soil cover plant species. Therefore, intercropping forage species, especially those from the genus Urochloa (Crusciol et al., 2012), with summer or winter crops can be an alternative to improve land use (Portes et al., 1995).

However, soil cover crops compete with grain crops in intercrops under water deficit conditions, thus reducing their productive potential (Silva et al., 2014). The use of selective herbicides and increased plant density of grain species to inhibit the development of the soil cover plants and to promote a rapid closure of the plant canopy is an alternative to reduce weed competition.

Managing sowing density is relatively simple, but has great effects on crop yields (Severino et al., 2006); moreover, the producer must consider edaphoclimatic characteristics, and the cultivar and soil management to be used (Severino et al., 2004). According to Souza-Schlick et al. (2011), plant densities of up to 70,000 plant ha-1 do not affect the castor bean grain yield. Moreover, when a crop species is intercropped with other economic-interest species, the crop population must be properly defined to avoid competition between species and, consequently, the decrease of their yield.

Intercropping grain crops with forage crops improve physical, chemical, and biological properties of the soil (Crusciol et al., 2010, 2012). However, information about intercrop of castor bean with grasses is not found in scientific literature. Urochloa ruziziensis is a grass species that has a $\mathrm{C} 4$ photosynthetic mechanism, thus, it grows faster than castor bean plants, which has a C3 photosynthetic mechanism. The hypothesis considered in this work is that increasing density of castor bean plants intercropped with $U$. ruziziensis leads to an early canopy closure, avoiding competition between species. Therefore, the objective of this work was to evaluate the productivity of castor bean plants intercropped at different plant densities with Urochloa ruziziensis.

\section{Material ANd Methods}

The experiment was conducted at the experimental farm of the University of the West of São Paulo (UNOESTE), in Presidente Bernardes, SP, Brazil (22 11' 53" S; 51 40' 30" W; and altitude of $401 \mathrm{~m}$ ). The soil of the experimental area was classified as distroferric Red Ultisol (EMBRAPA, 2013). The climate data collected during the experiment are presented in Figure 1.

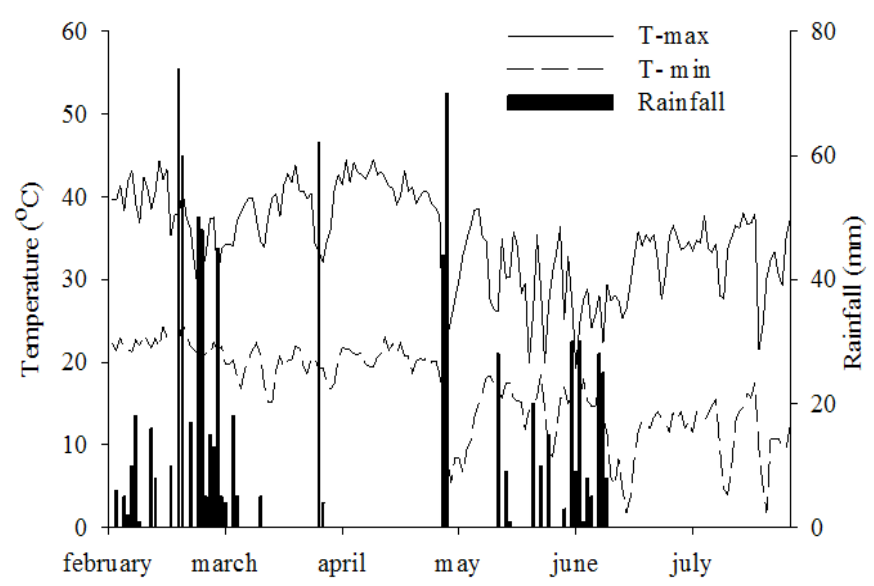

Figure 1. Monthly average maximum, minimum and accumulated rainfall during the experiment period

The experiment was conducted in a randomized block design with four replications, using a $4 \times 2$ factorial arrangement, consisting of four plant densities $(13,574,24,512$, 36,816 , and 40,723 plants ha ${ }^{-1}$ ) of castor bean and two crop systems (single crop, and intercrop with Urochloa ruziziensis between the castor bean plant rows).

Seeds of a simple-hybrid cultivar (AG IMA 110204) of castor bean were sowed on February 10, 2016, at density of 10 seeds per linear meter, with spacing of $0.80 \mathrm{~m}$ between rows. Planting fertilization consisted of $300 \mathrm{~kg} \mathrm{ha}^{-1}$ of the 04-30-10 N-P-K fertilizer. The plants were thinned 10 days after the germination of the castor bean plants according to the established densities. The recommended density for the cultivar used is 22,000 plants ha-1.

Viable seeds of $U$. ruziziensis at density of $7 \mathrm{~kg} \mathrm{ha}^{-1}$ was sowed manually 25 days after the castor bean germination. Topdressing fertilization was applied at 35 days after emergence (DAE) of castor bean plants, consisting of $49.5 \mathrm{~kg} \mathrm{ha}^{-1}$ of nitrogen (urea), and $42 \mathrm{~kg} \mathrm{ha}^{-1}$ of potassium (potassium chloride). The post-emergent, systemic, selective herbicide Clorimurom was applied $\left(80 \mathrm{~g}\right.$ a.i. ha $\left.\mathrm{ha}^{-1}\right)$ at $80 \mathrm{DAE}$, and a manual weeding was performed at $95 \mathrm{DAE}$ because of the low efficiency of the herbicide.

The castor bean plants were manually harvested at 165 DAE by collecting mature pods in each plot. The total number of plants, and number of harvested plants of each plot were counted, and the height of five random plants of each plot were measured. Five racemes with pods per plot were manually threshed to determine production components - number of grains per raceme, number of pods per plant, number of grains per pod, and 100-grain weight. The proportion of plants harvested (plants that have fruit structures) was determined by dividing the number of racemes harvested in five plants by five.

The data were subjected to analysis of variance by the F test and polynomial regression; and means were compared by the Tukey's test at 0.05 probability. Graphs were plotted using the Sigmaplot program.

\section{Results ANd Discussion}

The castor bean plant heights presented a quadratic response to plant densities; the highest heights were found in 
plants at density of 24,500 plants ha $^{-1}$ in both single crop and intercrop systems (Figure 2), which presented no significant differences for plant height.

Soratto et al. (2011) reported that an increase in plant density of castor bean from 25,000 to 70,000 plants ha ${ }^{-1}$ had no effects on plant height. However, the results of the present study showed a reduction of 10\% (single crop) and 5\% (intercrop) in plant height with increasing plant density from 24,512 to 40,723 plants ha ${ }^{-1}$. Bizinoto et al. (2010) found no differences in plant height of castor bean plants when using plant densities of up to 22,222 plants ha $^{-1}$. These differences may be due to characteristics of the production environment, cultivar, and sowing time, which determines the light and water availability, since both studies mentioned were conducted in the summer and the present work in the winter, period of low precipitation and luminosity.

Increasing the plant density from 13,574 to 40,723 plant ha- ${ }^{-1}$ reduced in $13 \%$ the proportion of plants harvested (Figure 3 ).

The results showed that increases in plant density reduces the proportion of plants harvested because of competition between plants. Bizinoto et al. (2010) found similar results

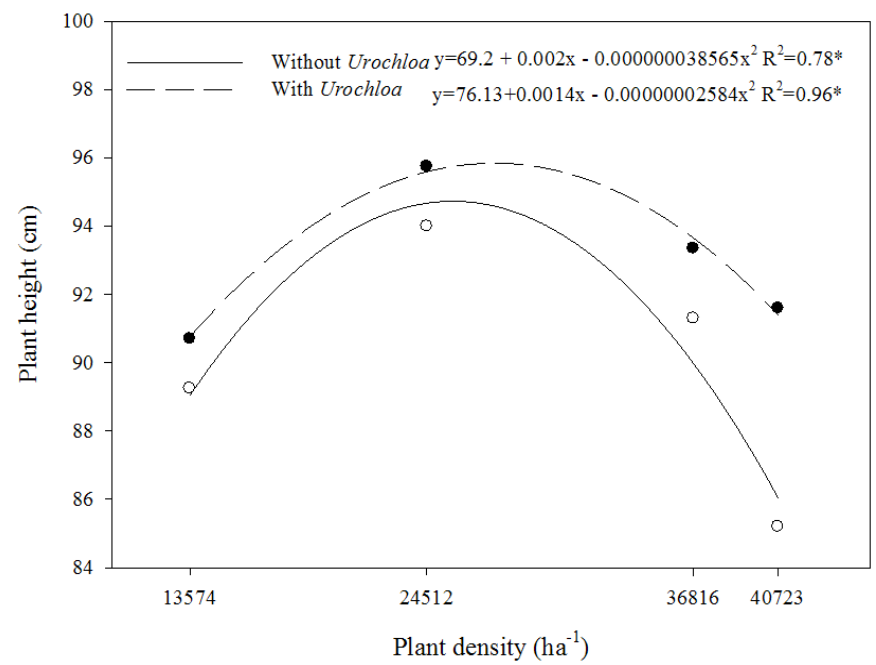

Figure 2. Heights $(\mathrm{cm})$ of castor bean plants, depending on plant densities and crop systems (single crop and intercrop with Urochloa ruziziensis in the interrow

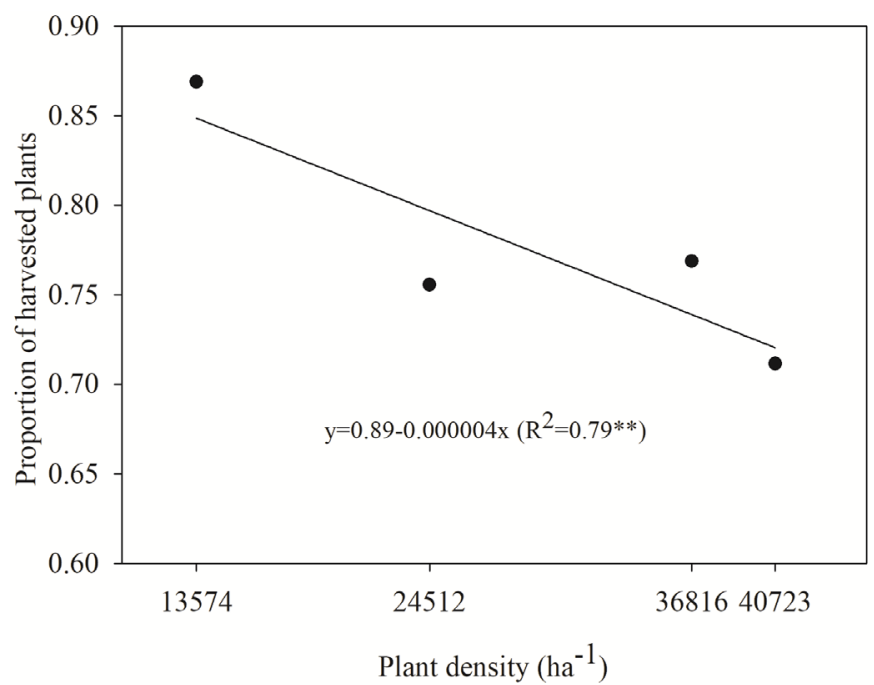

Figure 3. Proportion of castor bean plants harvested depending on plant densities when evaluated five densities ( 10 to 22 thousand plants ha' $\mathrm{a}^{-1}$ ) of castor bean plants. The light interception by plants is greater when using low densities, resulting in a higher biomass production and emission of racemes; whereas high plant densities lead to plants with lower number of racemes (Soratto et al., 2011). However, a low number of racemes not necessarily represents a low grain yield, since other important factors must be considered, such as plant density and grain weight (Alves et al., 2015).

The intercrop of castor bean with Urochloa ruziziensis reduced in $15 \%$ the number of pods per plant when compared to the single crop system (Figure 4). This variable is determined mainly by the plant genotype; however, the weed competition may have affected it negatively, causing a small decrease in this variable.

The interaction between plant density and crop system was significant for 100-grain weight, presenting a quadratic response, with the highest 100-grain weight at density of 29,000 plants $\mathrm{ha}^{-1}$; however, it presented a linear decrease in the single crop system, thus, the lowest grain weight was found in plants at the highest plant density (Figure 5).

Teixeira et al. (2011) evaluated the intercrop of common bean with castor bean and found no significant effects of the intercrop on the agronomic characteristics (number of racemes per plant, number of pods per racemes, and grain yield) of the castor bean crop. However, Oliveira Filho et al. (2016) reported that the intercrop of castor bean with cowpea or maize reduced the castor bean grain yield, however, this reduction is offset by a better land use efficiency. Moreover, intercropping two species increase interspecific competition (Vandermeer, 1992), which can be mitigated by the correct choice of the species to be intercropped, plant density (Oliveira Filho et al., 2016), and sowing time (Beltrão et al., 2010).

The highest grain yields were found in plants at density of 36,816 plants $\mathrm{ha}^{-1}$, both in the intercrop and single crop systems (Figure 6), with reduced yield from this density due to the increased competition between plants. The single crop and intercrop systems had no significant differences in grain yield; however, the yield was slightly lower in the intercrop system.

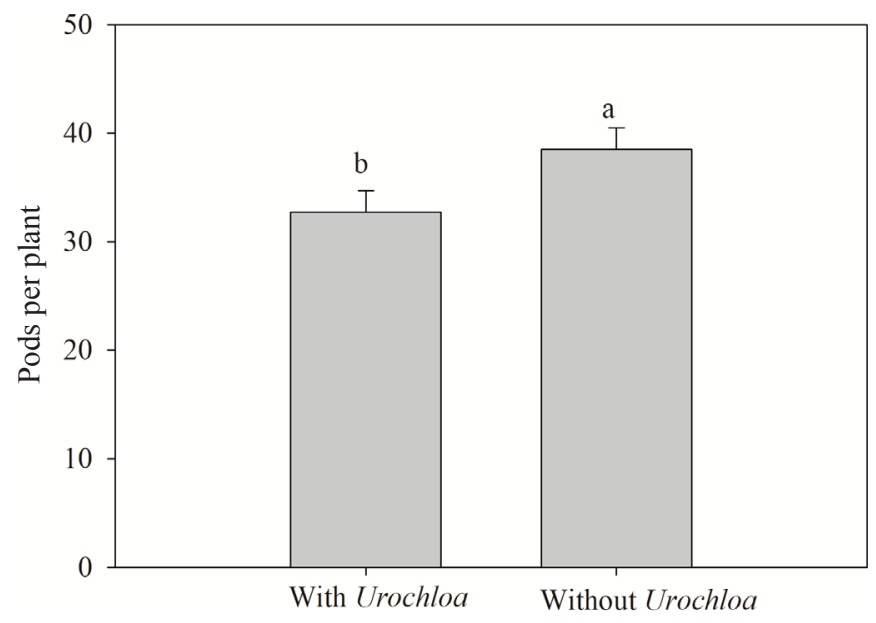

Means followed by the same letter do not differ by the Tukey's test at 0.05 probability $(p>0.05)$ Figure 4. Number of pods per plant of castor bean, depending on plant densities and crop systems (single crop and intercrop with Urochloa ruziziensis in the interrow) 


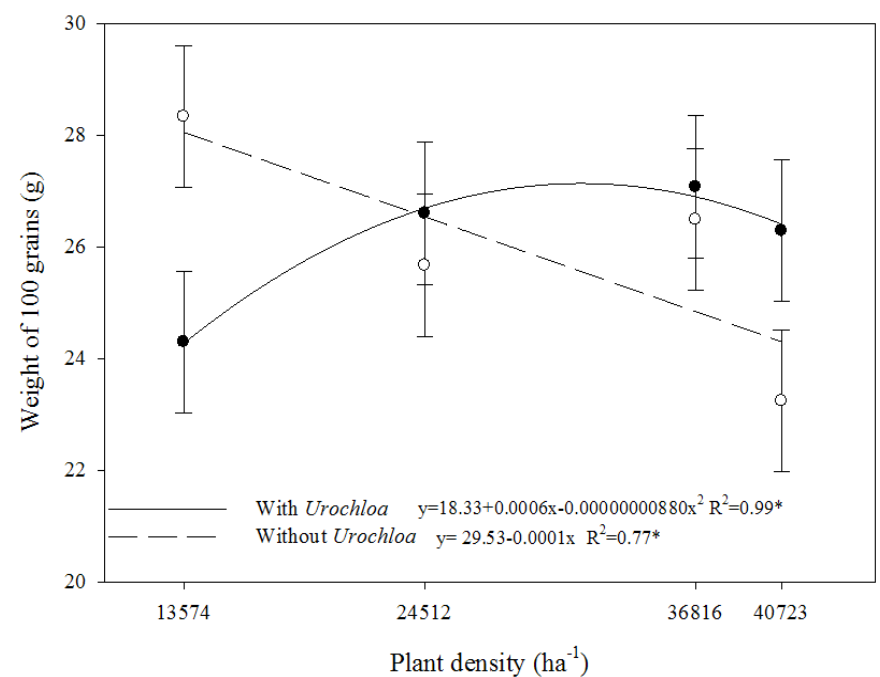

Figure 5. 100-grain weight of castor bean plants, depending on plant densities and crop systems (single crop and intercrop with Urochloa ruziziensis in the interrow)

Fioreze et al. (2016) found no decrease in the castor bean grain yield with a plant density of 111,111 plants ha ${ }^{-1}$, even with limitation of emission of secondary racemes. Similarly, the results of the present work showed increase of the castor bean grain yield with increasing plant density up to 36,816 plants ha $^{-1}$ (Figure 6), even with the reduction of the harvest index with increasing plant density (Figure 3).

According to Mateus et al. (2011), intercropping grass species of the genera Urochloa or Panicum does not affect the sorghum grain nutrition, and yield. Freitas et al. (2013) evaluated different plant densities of maize intercropped with $U$. ruziziensis and found a linear increase in grain yield, although the highest plant densities affected negatively the maize production components, denoting no effects of the intercrop system on the maize grain yield. Intercrops of castor bean with grass species are not common, but with other crop species, such as maize and bean, has been increasingly used to improve land use efficiency.

Corrêa et al. (2006) found no significant reduction in grain yield of castor bean plants intercropped with cowpea; however, intercropping castor bean plants with sorghum

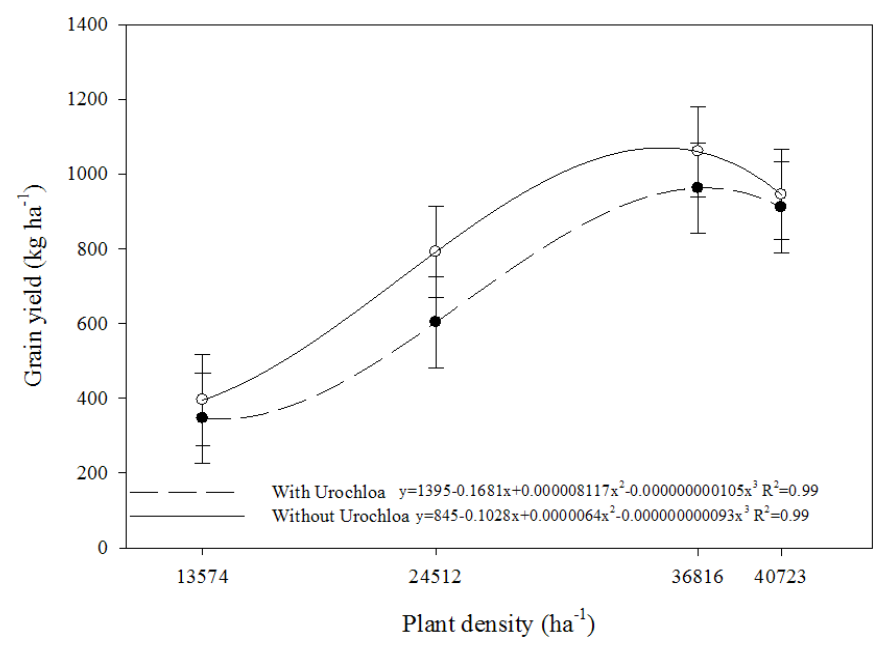

Figure 6. Castor bean grain yield $\left(\mathrm{kg} \mathrm{ha}^{-1}\right)$, depending on plant densities and crop systems (single crop and intercrop with Urochloa ruziziensis in the interrow) resulted in a reduction of $96 \%$ in the castor bean grain yield. This result may be due to the photosynthetic apparatus of the species used, since cowpea is a C3 plant and sorghum is C4 plant; $\mathrm{C} 4$ plants tend to suppress $\mathrm{C} 3$ plants because they have a greater growth in high luminosity conditions. Contrastingly, no significant reduction in castor bean (C3) grain yield was found in the present study when intercropped with Urochloa ruziziensis (C4).

The use of species of the genus Urochloa for intercrops with different grain crops is feasible mainly due to its slow initial growth, which reduces competition with the main crop (Jakelaitis et al., 2005). Moreover, the present experiment was conducted in the autumn and winter, which present decreased solar radiation, hindering the growth of $\mathrm{C} 4$ species. Therefore, the crop season affects directly the competition between different plant species in intercrop systems.

Thus, considering the production environment (West of São Paulo, Brazil), the intercrop of castor bean with U. ruziziensis does not significantly reduce the castor bean grain yield and is an alternative to produce crop residues for following crops.

\section{Conclusions}

1. The intercrop of castor bean with Urochloa ruziziensis has no effects on the productivity of castor bean plants.

2. Increasing the density of castor bean plants up to 36,816 plants ha ${ }^{-1}$ increase their grain yield in both intercrop and single crop systems.

\section{Literatura Citada}

Alves, G. da S.; Tartaglia, F. de L.; Ferreira, M. M.; Beutler, A. N.; Santos, E. dos C. Análise de crescimento da mamona BRS energia em função da densidade populacional. Revista Caatinga, v.28, p.167-175, 2015.

Beltrão, N. E. de M.; Vale, L. S. do; Marques, L. F.; Cardoso, G. D.; Maracaja, P. B. Época relativa de plantio no consórcio mamona e gergelim. Revista Verde de Agroecologia e Desenvolvimento Sustentável, v.5, p.67-73, 2010.

Bizinoto, T. K. M. C.; Oliveira, E. G.; Martins, S. B.; Souza, S. A.; Gotardo, M. Cultivo da mamoneira influenciada por diferentes populações de plantas. Bragantia, v.69, p.367-370, 2010. http:// dx.doi.org/10.1590/S0006-87052010000200014

Corrêa, M. L. P.; Távora, F. J. A. F.; Pitombeira, J. B. Comportamento de cultivares de mamona em sistemas de cultivo isolados e consorciados com caupi e sorgo granífero. Revista Ciência Agronômica, v.7, p.200-207, 2006.

Crusciol, C. A. C.; Mateus, G. P.; Nascente, A. S.; Martins, P. O.; Borchi, E.; Pariz, C. M. An innovative crop-forage intercrop system: Early cycle soybean cultivars and palisadegrass. Agronomy Journal, v.104, p.1085-1095, 2012. http://dx.doi.org/10.2134/ agronj2012.0002

Crusciol, C. A. C.; Soratto, R. P.; Borchi, E.; Mateus, G. P. Benefits of integrating crops and tropical pastures as systems of production. Better Crops International, v.94, p.14-16, 2010.

EMBRAPA - Empresa Brasileira de Pesquisa Agropecuária. Sistema brasileiro de classificação de solos. 2.ed. Rio de Janeiro: Embrapa Solos, 2013. 306p. 
Freitas, R. J. de; Nascente, A. S.; Santos, F. L. de S. População de plantas de milho consorciado com Urochloa ruziziensis. Pesquisa Agropecuária Tropical, v.43, p.79-87, 2013. https://doi. org/10.1590/S1983-40632013000100011

Fioreze, S. L.; Fioreze-Lara, A. C. da C.; Pivetta, L. G.; Rodrigues, J. D.; Zanotto, M. D. Características agronômicas da mamoneira afetada pelo método de condução de plantas e densidade de semeadura. Revista Ciência Agronômica, v.47, p.86-92, 2016. http://dx.doi.org/10.5935/1806-6690.20160010

Jakelaitis, A.; Silva, A. A. da; Ferreira, L. R. Efeitos do nitrogênio sobre o milho cultivado em consórcio com Brachiaria brizantha. Acta Scientiarum. Agronomy, v.27, p.39-46, 2005. http://dx.doi. org/10.4025/actasciagron.v27i1.1916

Mateus, G. P.; Crusciol, C. A. C.; Borchi, E.; Pariz, C. M.; Costa, C.; Silveira, J. P. F. da. Adubação nitrogenada de sorgo consorciado com capim em sistema de plantio direto. Pesquisa Agropecuária Brasileira, v.46, p.1161-1169, 2011. http://dx.doi.org/10.1590/ S0100-204X2011001000007

Oliveira Filho, A. F.; Bezerra, F. T. C.; Pitombeira, J. B.; Dutra, A. S.; Barros, G. L. Eficiência agronômica e biológica nos consórcios da mamoneira com feijão-caupi ou milho. Revista Ciência Agronômica, v.47, p.729-736, 2016. http://dx.doi. org/10.5935/1806-6690.20160087

Portes, T. de A.; Oliveira, I. P. de; Kluthcouki, J. Competição entre capim braquiária e cereais consorciados no Sistemas Barreirão. Santo Antônio de Goiás: Embrapa Arroz e Feijão, 1995. 10p. Comunicado Técnico, 29

Sá, R. O.; Galbieri, R.; Bélot, J. L.; Zanotto, M. D.; Dutra, S. G.; Severino, L. S.; Silva, C. J. da. Mamona: Opção para rotação de cultura visando a redução de nematoides de galha no cultivo do algodoeiro. Primavera do Leste: Instituto Mato-Grossense do Algodão, 2015. 12p. Circular Técnica, 15
Savy Filho, A.; Banzatto, N. V. Mamona (Ricinus communis L.). In: Jorge, J. A.; Lourenção, A. L.; Aranha, C. (eds.). Instruções agrícolas para o Estado de São Paulo. Campinas: Instituto Agronômico de Campinas, 1990. p.132-133. Boletim Técnico, 200

Severino, L. S.; Moraes, C. R. de A.; Ferreira, G. B.; Gondim, T. M. de S.; Freire, W. S. A.; Castro, D. A. de; Cardoso, G. D.; Beltrão, N. E. M. Adubação química da mamoneira com NPK, cálcio, magnésio e micronutrientes em Quixeramobim. In: Congresso Brasileiro de Mamona, 1, 2004, Campina Grande. Anais... Campina Grande: Embrapa Algodão, 2004. p.1-5.

Severino, L. S.; Moraes, C. R. de A.; Gondim, T. M. S.; Cardoso, G. D.; Beltrão, N. E. M. Crescimento e produtividade da mamoneira influenciada por plantio em diferentes espaçamentos entre linhas. Revista Ciência Agronômica, v.37, p.50-54, 2006.

Silva, F. A. M. da; Evangelista, B. A.; Malaquias, J. V.; Guerra, A. F.; Rocha, O. C. Parâmetros hídricos, área foliar e coeficiente cultural (Kc) do consórcio milho-braquiária irrigado. Planaltina: Embrapa Cerrados, 2014. 26p. Boletim de Pesquisa e Desenvolvimento, 316 Soratto, R. P.; Souza-Shlick, G. D.; Giacomo, B. M. S.; Zanotto, M. D.; Fernandes, M. A. Espaçamento e população de plantas de mamoneira de porte baixo para colheita mecanizada. Pesquisa Agropecuária Brasileira, v.46, p.245-253, 2011. http://dx.doi. org/10.1590/S0100-204X2011000300004

Souza-Schlick, G. D.; Soratto, R. P.; Pasquali, C. B.; Fernades, A. M. Desempenho da mamoneira IAC 2028 em função do espaçamento entre fileiras e população de plantas na safrinha. Bragantia, v.70, p.519-528, 2011. http://dx.doi.org/10.1590/S000687052011000300006

Teixeira, I. R.; Silva, G. C. da; Timossi, P. C.; Silva, A. G. da. Desempenho agronômico de cultivares de feijão-comum consorciado com mamona. Revista Caatinga, v.24, p.55-61, 2011.

Vandermeer, J. The ecology of intercropping. New York: Cambridge University Press, 1992. 237p. 